UDK: $579.834 .114: 616.98$

\title{
BORRELIOSIS: A HIDDEN THREAT FOR KAZAKHSTAN
}

Bissenbay A.O., Zhigailov A.V., E.R. Maltseva, Egemberdieva R.A., Skiba Y.A., Mamadaliyev S.M.

National Center for Biotechnology, Almaty Branch

14, Zhahanger str., Almaty, 050054, Kazakhstan

andrzhig@yandex.ru

\section{ABSTRACT}

Tick-borne borreliosis, commonly known as Lyme disease or Lyme borreliosis, is a natural focal zoonotic transmissive disease caused by the Borreliella burgdorferi sensu lato complex. If left untreated, the disease can cause damage to the nervous system, joints, or skin, as well as lead to development of chronic atrophic diseases. Diagnosis of borreliosis remains a challenge owing to variations in clinical symptoms and manifestations, simultaneous damage to several organs, and frequent latent persistence of the pathogen in the body, leading to misdiagnosis or late diagnosis. This situation results in defects or delays in the provision of medical care with a high frequency of residual consequences, resulting in temporary disability for the patient that imposes a significant social-economic burden. Ticks of the genus Ixodes are the main carrier of the disease, which inhabit the mountain regions of eastern and southeastern Kazakhstan. However, the distribution area of these ticks has been expanding in recent years owing to the effects of climate change, resulting in an increase of natural foci of tick-borne borreliosis. We here provide updated data on the epidemiology, etiology, pathogenesis, and diagnostic methods for Lyme borreliosis, along with an overview of modern molecular methods for the analysis of borrelia. Moreover, we offer an overall assessment of the risks associated with this disease for Kazakhstan.

Keywords: Lyme disease, Borreliella burgdorferi sensu lato, Ixodes, erythema, genotyping, genospecies

\section{INTRODUCTION}

\section{General information}

Lyme disease (ICD 10:A69.2; synonyms: tickborne Lyme borreliosis, Ixodes tick-borne borreliosis, chronic migratory erythema, tick-borne erythe$\mathrm{ma}$ ) is a natural focal, polysystemic, vector-borne disease caused by species of Borreliella burgdorferi sensu latu complex. This disease is characterized by a staged course with a predominant lesion of the skin, cardiovascular system, musculoskeletal system, nervous system, rarely other organs and systems. Tick-borne borreliosis is characterized by the polymorphism of the clinical picture, the unclear manifestations in the early stages, simultaneous damage of several organs and systems, leading to errors and late diagnosis of the disease, defects in the provision of medical care, high frequency of residual consequences and, as a result, serious socio-economic losses associated with temporary disability and even permanent disability of infected people [1].

\section{Description of the pathogen}

Borrelia is a gram-negative spiral-shaped bacteria (spirochetes). Their cell wall consists of an outer lipid membrane, a protoplasmic space in which about a dozen flagella are localized, and a cytoplasmic inner membrane surrounding the contents of the cytoplasm. An important difference between borrelia and other gram-negative bacteria is the absence of classical lipopolysaccharides on the outer surface of the cell. Instead, borrelia contain a large number of su- 
perficially located lipoproteins (OspA, OspB, OspC, OspD, OspE, and OspF), with about $8 \%$ of the open reading frames in the borrelia genome encode lipoproteins [2]. The genes of these lipoproteins are expressed in various combinations during transmission of the microorganism from the tick to the host mammal and play a significant role in the pathogenesis of the infections they cause [2].

Recently, after full genome sequencing of borrelia [3] and numerous genomics studies of these spirochetes, the genus Borrelia was proposed to be divided into two genera (Borrelia and Borreliella), which formed new family - Borreliaceae [4].

At the same time, it is proposed to include in the genus Borrelia only spirochetes that cause recurrent borrelia typhoid fever (recurrent fevers), and other borrelia, including species causing Lyme disease in humans, into the genus Borreliella [5]. This decision was made after a long debate among research groups and clinicians and is based on an in-depth molecular analysis of phylogenetic and phenotypic characteristics, that is, a comparison of genomes and proteomes from increasingly accessible omics data, but this issue has not been fully resolved, and there is not a complete agreement concerning these changes in borrelia taxonomy.

Based on the common genetic characteristics, several species of the genus Borreliella are combined into the supraspecific B.burgdorferi sensu lato complex. Currently, it includes up to twenty genospecies: B. afzelii, B. bavariensis, B. bissetti, B. burgdorferi (sensu stricto), B. finlandensis, B. garinii, B. lusitaniae, B. spielmanii, B. valaisiana, etc.) [6].

But only certain genospecies of to this supraspecific complex have proven pathogenicity for humans. In North America, it is almost only B. burgdorferi sensu stricto that is capable of causing borreliosis in humans. In Eurasia, at least five genospecies are capable of causing Lyme borreliosis (B. afzelii, B. garinii, $B$. burgdorferi s.s., $B$. spielmanii and $B$. bavariensis). [7]. Three more genotypes of the genogroup B. burgdorferi s. 1. (B. bissettii, B. lusitaniae and B. valaisiana), although in rare cases detected in humans, are not considered important pathogens for Lyme borreliosis. The main causative agents of Lyme borreliosis in Europe are B. afzelii and B. garinii. In Asia, the most distributed genospecies is $B$. garinii [8]. Each of the three main genospecies of B. burgdorferi s. 1., causing Lyme borreliosis (B. burgdorferi s.s., B.afzelii and B. garinii) is tropic to certain organs and systems. Skin lesions (such as chronic acroder- matitis) are more characteristic for B. afzelii, harm to the nervous system (neuroborreliosis) - for $B . g a-$ rinii, and arthritis for $B$. burgdorferi s.s. $[8,9]$. But, at the same time, each of these three genospecies can cause damage in any localization.

Genetic studies have revealed an almost complete absence of biosynthetic pathways, which makes the microorganism of these spirochetes dependent on the environment for nutritional needs. However, borrelia causing Lyme disease can be cultured in vitro on enriched culture media [10].

\section{Epidemiology}

Lyme borreliosis is found on all continents except Antarctica. The geographical distribution of this disease coincides with the distribution area of tickborne encephalitis. This is due to the commonality of natural reservoirs (warm-blooded vertebrates) and carriers.

The natural reservoir of $B$. burgdorferi s. 1 . are mice, voles, chipmunks and other small mammals, as well as some species of birds [11]. In the European part of Russia, the main reservoir of Borreliella is the bank vole Cletrionomys glareolus, and east of the Ural Mountains this species as a reservoir is gradually replaced by C. rufocanus and C. rutillus; in some places, an important role as a reservoir of borrelia in Russia is played by mice of the genus Apodemus [12]. Deer and cattle are not competent hosts for $B$. burgdorferi, but they are important for maintaining the life cycle of tick vectors [13]. Different genospecies of B. burgdorferi s.l. have their own preferences regarding their hosts, although these preferences are not absolute [7].

Among birds, natural infection with borrelia and the ability to transmit the pathogen to ticks has been proven in pheasants, some passerines, including thrushes, as well as in seabirds, associated with $I$. uriae [14].

The carriers of the disease are ticks of the genus Ixodes. I. scapularis and I. pacificus are the main vectors of Lyme borreliosis in North America (distributed on the West and East coasts of the USA, respectively), while I. ricinus is the main carrier of the disease in Europe [15], and I. persulcatus - in Asia [7]. In Kazakhstan, Lyme borreliosis is most likely transmitted by I. persulcatus and I. ricinus [16].

There are reports in the literature that borrelia can be isolated in rare cases from ticks of other genera, for example, from Dermacentor spp. [17]. The role of these ticks in the spread of Lyme borreliosis is 
unclear. Perhaps they can act as mechanical carriers of borrelia.

In Europe, the number of cases of Lyme borreliosis reaches 338 per 100,000 people in Belgium and 464 per 100,000 people in Sweden. In the USA, the total number of confirmed Lyme borreliosis cases was 29.5 cases per 100,000 people in 2017.

In the CIS, a fairly high prevalence of Lyme disease is recorded in Belarus - (15.8 cases per 100,000 people). The number of cases recorded in Ukraine in 2012 amounted to 3.6 per 100,000 people, and in the Russian Federation in 2011 - 7 cases per 100,000 people [18]. There is an assumption that over 12,000 new cases of Lyme borreliosis are detected annually in the Russian Federation [16].

\section{Etiology and pathogenesis}

Ixodid ticks have four life cycle stages: an egg, a larva, a nymph and an adult (imago). Active forms of ticks require blood saturation to go to another phase of the life cycle. After feeding for several days (about three days for larvae, five for nymphs and seven days for adult females), the ticks fall off from their host and are localized on or near the soil surface, where they need a minimum relative humidity of $80 \%$ to survive. Once there, the ticks take several months to go to the next stage of development, or, in the case of adult females, in order to lay about two thousand eggs. The life span of ticks varies from 2 to 6 years, depending on the climate, the host, and the availability of diapause.

Tick infection occurs mainly during feeding of larvae and nymphs on infected vertebrates, during joint feeding of infected and uninfected ticks, as well as through sexual contact [14]. Cases of transovarial transmission of the pathogen to larvae have been described [19]. The pathogen hibernates both in ticks and in small mammals (some of them are characterized by long-term carriage of borrelia).

The causative agents of Lyme borreliosis can be found both in tick adults and nymphs, and only in extremely rare cases can they be isolated from tick larvae. The causative agents of borreliosis are transmitted to a warm-blooded host with tick saliva (in most cases, this takes 24 hours). So, for transmission of B. burgdorferi to humans from ticks I. scapularis or I. pacificicus, a feeding period of more than 36 hours is usually required. The transmission of $B$. afzelii and B. garinii probably requires less time (about 17 hours) [7]. At the same time, cases of transmission of the pathogen were recorded even during the first hours from the moment of tick bite (in case of generalized tick infection). [18]. Often, an early transmission of Borreliella occurs due to improper extraction of the ticks (when pressing on the abdomen during extraction or when the tick is placed in a drop of vegetable oil). It is possible to transfer borrelia through tick feces if they get on the skin and then are rubbed into the skin when scratched. [1]. Cases of mechanical transmission of borrelia in the event of accidental crushing of ticks during their removal from animals and the transfer of the contents of the tick intestine in skin microtraumas or on the conjunctiva of the eyes are not excluded. The possibility of fetus transplacental infection with borreliosis is also proven in pregnant women [1].

Spontaneous tick infection with Borreliella in natural foci can range from 10 to $70 \%$ or more. Infection of adult hungry $I$. ricinus ticks with borrelia usually does not exceed 20-40\%, and in I. persulcatus it can reach $90 \%$ or more. Infection of nymphs is usually much lower, and larvae infection rarely exceeds 5\% [19]. Seven to fifty percent of ticks in the endemic focus can be infected simultaneously with two or three different borrelia [14]. The annual dynamics of Lyme disease morbidity is characterized by pronounced seasonality associated with the period of carrier activity.

Borreliella is able to persist for a long time in a metabolically inactive state in the middle intestine of ixodid ticks. When an infected tick takes blood meal, the number of spirochetes increases dramatically, their cells undergo phenotypic changes. In particular, the expression of the surface protein OspC begins in their cells, which allows the borrelia to penetrate into the salivary glands of the sucking tick, and then into the cells of the warm-blooded vertebrate.

With tick saliva, the causative agent of Lyme disease enters the human or animal body. At the first stage of the disease, Borreliella accumulate in the skin at the site of a tick bite and replicate, spreading centrifugally and leading to the activation of the local immune system of the at the site of introduction of pathogens. This usually leads to the development of migratory circular erythema.

Spirochetes gradually spread throughout the body. Their distribution is facilitated by binding to thrombocytes via integrin aIIb b3 and to endothelial cells through integrins avb3 and a5b1. An important role in the adhesion and colonization of borrelia throughout the host organism is played by the surface proteins $\mathrm{DbpA}$ and $\mathrm{DbpB}$, which are capable of 
binding proteoglycan decorin [20]. Another important adhesin of borrelia is BBK32, a fibronectin-binding protein that facilitates $B$. burgdorferi attachment to glucosaminoglycans (GAG) [21]. The ability of proteins to bind to host cell matrix proteins is not the only way that borrelia can efficiently spread to different parts of a mammalian host. An important role in this process is also played by chemotaxis and the apparatus of motility of spirochete cells [22].

Although $B$. burgdorferi do not produce endotoxins, lipoproteins (mainly OspA, OspB and OspC) embedded in their lipid membranes are able to interact with Toll-like receptors (TLRs) on the surface of mammalian cells responsible for the development of a non-specific T-cell response, which leads to the release of inflammatory products by these immune cells, which ultimately leads to damage of the cells and tissues of the body [1].

Some research groups have reported the discovery of a new strong neurotoxin, Bbtox1, produced by B. burgdorferi [38]. At the same time, no scientific article has yet been published in a peer-reviewed rating publication that would confirm these reports. The data of the genomic sequence of Borreliella ( $B$ burgdorferi is the first spirochete for which full-genome sequencing was performed) did not reveal the presence of genes encoding the key structural elements of any known bacterial exotoxin or components of the secretory apparatus necessary for the export and delivery of exotoxin [3, 23].

The appearance of borrelia in the body leads to the activation of a B- and T-cell immune response. The severity of the disease depends not only on the type and genotype of the pathogen, the location of the primary infection, the age and condition of the patient, but also on which alleles of the main histocompatibility complex are expressed in human cells [24].

Most reactions to infection (including erythema migrans) are mediated by adverse reactions of human immunity to infection [7].

Due to the presence of certain virulence factors in borrelia (the use of various mechanisms for adhesion, colonization and invasion, as well as the presence of proteins toxic to the host organism), the immunity to borrelia is unsterile, and the pathogen can persist for many months and even years [25].

Borreliella use a number of mechanisms to allow them to avoid the host's immune response. So, Borrelia produce surface lipoproteins called CRASPs (complement regulatory acquiring surface proteins). These proteins are able to bind the $\mathrm{H}$ and FHL-1 factors involved in triggering an alternative complement activation pathway. To date, several B. burgdorferi CRASPs are known: CspA, CspZ, ErpA, ErpC, OspE, p21, and ErpP [26].

Inhibition of antibody-dependent lysis of borrelia cells is also blocked by inactivation of the main participant in the complement system, C3b protein [27]. By inducing anti-inflammatory interleukin IL-10, borrelia inhibit the body's early immune responses [28]. The next strategy of borrelia, which allows them to avoid the immune response, is the production of soluble, non-membrane-bound surface antigen molecules that bind to specific antibodies in the bloodstream, cerebrospinal fluid, and other body fluids to form immune complexes [29]. This strategy allows spirochetes to remove lytic antibodies from the bloodstream, preventing the opsonization of their cells.

The most numerous surface proteins of Lyme borreliosis pathogens are the so-called Osps: OspA, OspB and OspC. One of their tasks is the transmission to the cells of various hosts (ticks and mammals). The expression of the genes encoding them varies, depending on the environment in which the borrelia cell is located. Another surface lipoprotein is the $35-\mathrm{kDa}$ vlsE lipoprotein. Like trypanosomes, the process of continuous change in surface antigenic epitopes by recombination of genes encoding this surface protein is realized in spirochete cells [30]. $B$. burgdorferi cells carry a 28-kilobase linear plasmid that encodes 15 silent vls-cassettes adjacent to the transcriptionally active expression site (vlsE) [31]. Recombination of these genes allows spirochetes to constantly change the immune determinants of surface proteins, minimizing the body's B-cell immune response.

The ability of spirochetes to bind to various components of the extracellular matrix can also contribute to the long-term preservation of borrelia in humans and animals [32]. In this case, chronic lesions of one particular localization (skin, musculoskeletal system or nervous system) develop, depending on the tropism of the pathogen to one or another locus (stage 3 of the disease) [1].

As the disease progresses, autoimmune mechanisms become more and more significant in pathogenesis. This is due to the fact that some antibodies produced in response to infection with borrelia (e.g., to the OspA protein) have cross-immunological activity against both Borreliella antigens and tissue proteins (e.g., axonal proteins of the nervous tissue 
and synovial membrane proteins) [33].

\section{Clinical manifestations}

The incubation period of the disease varies from 3 to 32 days. Three stages are distinguished in the development of the disease: early localized, early disseminated and late stage. These stages can occur sequentially or, in rare cases, overlap each other, so the division at the stage of the disease is often very arbitrary [1].

Early or localization stage of Lyme borreliosis. The first stage of Lyme borreliosis is characterized by the appearance of a migrating erythema at the tick bite site, which is a ring-shaped or solid spot from pale pink to bright red in color, gradually increasing in diameter [13]. Erythema migrans is a pathognomonic symptom of Lyme disease, and, if present, the clinical diagnosis is absolutely valid. The average diameter of erythema is $5 \mathrm{~cm}$, but it can reach $60 \mathrm{~cm}$ (in the absence of treatment) and persist for 3-4 weeks from the start of its development [34]. In some patients, migratory erythema is asymptomatic, but many patients have nonspecific symptoms, including fatigue, headache, arthralgia, myalgia. In the early stages of early localization, patients usually do not complain of fever. In extremely rare cases a primary affect in the form of a sore or crust is observed in the place of tick bite.

The second or disseminated stage of Lyme borreliosis. The second stage of Lyme borreliosis is characterized by the development of signs of damage to several organs and systems simultaneously (skin, musculoskeletal system, nervous and cardiovascular systems), sometimes - the appearance of subfebrile fever and constitutional symptoms. This stage develops, as a rule, after a month or more from the moment borrelia enters the human body, more often in the second or third month of the disease, up to a maximum of 6 months. At the disseminated stage of the disease, neurological conditions can occur, such as paralysis of one of the cranial (especially facial) nerves and meningitis, which mimics aseptic meningitis, as well as carditis, which most often manifests itself as heart block.

During the disseminated stage of Lyme borreliosis usually only one of the above symptoms appears in one patient.

The third or late stage of Lyme borreliosis. The late stage of Lyme borreliosis develops after 6 months or more from the moment of infection with B. burgdorferi s. 1. It is characterized by the harm of mainly one system: the musculoskeletal system, skin or nervous system [1]. In the case of Lyme arthritis, large joints are primarily affected. Swelling of the affected joints, pain and restriction of movements develop. Manifestations of Lyme arthritis can last from several weeks to several months with periods of complete remission between them [35]. The most serious lesions from a clinical point of view are characteristic of late neuroborreliosis. This condition often occurs in the form of disseminated encephalomyelitis or subacute Lyme encephalopathy. In a quarter of patients, pathological changes in the brain are detected by MRI scan, in some cases imitating the picture of multiple sclerosis or other demyelinating lesions of the central nervous system. Subacute Lyme encephalopathy is characterized by gradually progressing intellectual-mnestic disorders, asthenia, irritability or depression, behavioral disorders in the absence of objective neurological abnormalities and pathological changes in the brain substance during neuroimaging [1].

Post-Lyme syndrome. $10-20 \%$ of patients with clearly diagnosed Lyme borreliosis who received the correct antibiotic treatment may develop long-lasting (up to 12 or more months) somatic and/or neurocognitive symptoms of mild to moderate intensity without obvious clinical and laboratory signs of active infection caused by B. burgdorferi. Objective evidence of Borreliella infection of patients with post-Lyme syndrome is usually not found neither by PCR nor using cultural methods. The most common symptoms of post-Lyme syndrome are constant fatigue syndrome, arthralgia, myalgia, headache, stiff neck, paresthesia, insomnia, irritability and memory problems, cognitive impairment (problems with word selection and concentration) [35].

Chronic Lyme disease (chronic borreliosis). Patients diagnosed with Lyme disease who receive timely antibiotic treatment usually recover completely without serious health consequences. At the same time, if treatment was started in the later stages, the chance of developing chronic manifestations of the disease is rather high [36]. The term chronic Lyme disease is used to describe the chronic manifestations of borreliosis when it is impossible to establish the fact of person's infection with B. burgdorferi (after successful antibiotic therapy or if the causative agent of borreliosis has not been detected, but there are indirect signs of the disease).

Co-infections. Ixodes spp. ticks can be co-infected and transmit Borreliella causing Lyme disease 
together with other pathogens, such as Anaplasma phagocytophilum, Babesia spp. and tick-borne encephalitis virus [36]. Therefore, sometimes other symptoms that are not characteristic of the disease are mixed with the obvious symptoms of Lyme disease. In this case, co-infection with other pathogens cannot be excluded.

\section{Laboratory diagnostics}

Serological methods are in most cases the only effective way to determine the incidence of borreliosis in humans in a laboratory. At the same time, specific immunoglobulins for B. burgdorferi usually appear only a few (3-6) weeks after the pathogen enters the human body. Therefore, enzyme-linked immunosorbent assay (ELISA) is usually used only to clarify the diagnosis and only occasionally (in the case of non-erythema manifestations of Lyme borreliosis) - as the main means for proposing a diagnosis. An increase in the titer of IgG antibodies in paired sera (in the acute period of infection and the recovery period), as well as an increase in the levels of IgG and IgM, indicate the presence of Lyme disease [37].

IgG specific for borrelia immunoglobulins can be maintained at a high level for several months and even years after the end of antibiotic therapy [37]. ELISA using antibodies to the C6 peptide of the variable lipoprotein VlsE (C6VlsE) as the only test for Lyme disease at any stage, has a sensitivity and specificity similar to or even higher than that of a conventional ELISA, but the specificity of this test is lower than that of the two-level test [38].

The first IgM antibodies appear only after 3 weeks from the moment of infection, and IgG appear on week 4-6. Therefore, in the early stages of the disease, it is not advisable to use serological methods for diagnostic purposes: there is a high risk of receiving false negative result. In late borreliosis, IgG is always detected. Therefore, the detection of only IgM without IgG to B. burgorferi after 1 month after the suspected contact with the pathogen should be regarded as a nonspecific false-positive result. To confirm the positive results of screening, it is recommended to use immunoblotting method, which allows detecting antibodies to individual specific proteins of the cell wall of Borreliella. Such a protocol is recommended as the "goldend standard" and the main diagnostic method for Lyme borreliosis in most international recommendations [15].

Direct methods for identifying Lyme disease pathogens include the bacteriological method of cultivating spirochetes on culture media and PCRbased methods. Both of them show extremely low sensitivity in the study of almost all biological samples, with the exception of synovial fluid and erythema biopsies, which is caused by low spirochetes content in clinical samples. It should be noted that recently the sensitivity and specificity of PCR diagnostics have increased [39]. The bacteriological method is still characterized by complexity, high cost and time needed for analysis. Nevertheless, it is still used in reference laboratories and most often for scientific purposes for the study of skin biopsies with erythema migrans and synovial fluid with Lyme arthritis [1]. Samples of plasma, serum, whole blood, and cerebrospinal fluid are not suitable for the detection of borrelia by the bacteriological method [1] Different genotypes and genospecies of Borreliella have different ability to reproduce in vitro.

Molecular methods based on PCR are mainly used to detect borrelia nucleic acids in ticks or in skin biopsies [39]. At the same time, a positive result means that the tick is infected, but does not allow predicting the likelihood of pathogen's transmission.

\section{Treatment and prevention of the disease}

Since specific antibodies to B. burgdorferi s. 1 . usually appear a few weeks after the tick bite, it is considered unjustified to use observational practice for patients with erythema migrans or the intention to detect antibodies to the causative agent of borreliosis by serological methods in the early stages of the disease. In this case, false-negative results of laboratory diagnostics and the risk of the transition of tickborne borreliosis to the next stage without antibiotic therapy can be expected. Therefore, with the manifestation of migratory erythema, which is currently considered an integral clinical sign of Lyme borreliosis, it is reasonable to use antibiotic therapy, especially if it was established that the patient could be subjected to a tick bite in the Lyme disease endemic area. [13].

There are currently no reports of acquired resistance of B. burgdorferi s. 1 . to antibiotics used to treat Lyme disease. A study conducted in 2012 on European strains of Borreliella showed a $100 \%$ sensitivity of the pathogen to doxycycline, amoxicillin, cefuroxime, ceftriaxone and azithromycin. These antibiotics can be used in the treatment of tick-borne borreliosis, while the choice of a specific agent is determined to a greater extent by the stage of the dis- 
ease. Doxycycline is the drug of choice in all patients with an early-localized stage of tick-borne borreliosis. If there are contraindications for the administration of doxycycline (children under 8 years old, pregnant women), it is possible to use beta-lactam antibiotics (amoxicillin, cefuroxime) and only if there is an allergy to those it is possible to use macrolides (clarithromycin, azithromycin). However, according to reported data, beta-lactam antibiotics and macrolides are less clinically effective compared to doxycycline [1].

Effective antibiotic treatment makes finding other ways to fight Lyme disease unprofitable. At the same time, there are known phages that infect B. burgdorferi [40].

Awareness of people regarding the etiology and symptoms of Lyme disease can significantly reduce the incidence of Lyme borreliosis in areas endemic for the disease. The use of appropriate clothing, repellents, as well as taking a bath after staying in a forest or mountains, to a significant extent minimizes the risk of tick attack. Early removal of sucking ticks after a timely examination of the skin after going to nature (using the correct practice of removing ticks) reduces the chance of Borreliella getting into the human body, even from ticks that are carriers of B. burgdorferi s. 1. Cleaning leaves in crowded places where the tick population is high (parks) is also an effective preventive method for combating tick-borne borreliosis. In Lyme disease endemic regions it is recommended to use post-exposure chemoprophylaxis after each tick bite (doxycycline orally in a dose of $200 \mathrm{mg}$ in the first 72 hours from the moment the tick bite), which reduces the likelihood of developing the disease by 12 times compared with the absence of chemoprophylaxis. Vaccines for the prevention of Lyme borreliosis have not yet been developed, although a number of studies have been conducted that prove the possibility of obtaining effective vaccines against borrelia and their feasibility. So, it was demonstrated that antibodies to the surface protein of B. burgdorferi DbpA inhibit the development of infection [41]. Potential vaccines based on the use of the OspA protein are also considered effective [42].

\section{Genetic characterization of borrelia}

Numerous studies involving a wide variety of molecular genetic techniques, such as ribosomal RNA sequence analysis, macro-restriction pattern variation, multilocus sequence analyses (MLST/MLSA), RFLP analysis (restriction fragment polymorphism analysis) and others have demonstrated a significant degree of genomic variability in different borrelia species [43, 44]. There were also differences in the composition of plasmids found in borrelia cells [45].

Genetic variation of B. burgdorferi s.l. has a significant impact on the pathogenicity, the intensity of the developing immune response to the pathogen, the clinical picture, transmission mechanisms, ecology and even the degree of their detectability, which has been demonstrated in a number of studies [46].

Of great importance is the genetic diversity in the genes of the main antigens of B. burgdorferi, which mediate the development of protective reactions of the organism, for example, in the ospC gene encoding one of the surface lipoproteins of borrelia. Recently, a large number of ospC alleles have been recorded. The divergence of the sequence of ospC alleles may exceed $8 \%$, and currently about 20 major groups of these alleles are recorded in each of the three main pathogenic genospecies of $B$. burgdorferi (B. burgdorferi s.s., B. afzelii and B. garinii). In the course of large-scale studies, it was shown that spirochetes carrying different groups of ospC alleles can mediate diseases with a different clinical picture, with a different tendency to develop chronic manifestations of Lyme borreliosis [43].

\section{Data on the distribution of Lyme borreliosis in Kazakhstan}

Lyme borreliosis is detected in Kazakhstan [47], however, epidemiological data on Lyme disease in Kazakhstan is not available. The official registration of this disease began in 2012 [47]. East Kazakhstan and Almaty regions are considered endemic for Lyme disease, although data appears increasingly on the occurrence of this disease in non-endemic regions, for example, in the Akmola region [48]. Currently, open sources of information do not provide data on which genospecies of borrelia are common in Kazakhstan, and information on the level of tick infection with borrelia is extremely scarce. Ticks of the genus Ixodes have natural foci of distribution in East Kazakhstan and Almaty oblasts of the Republic of Kazakhstan, although recently due to climate change their distribution area has been steadily expanding; ticks of this genus are now found in Pavlodar, Kostanay and Zhambyl oblasts of Kazakhstan.

The most common (also the main potential carrier of borrelia) tick species in Kazakhstan is I. persulcatus. The main distribution area of this species extends to the Tien Shan, Dzungarian and Zailiysky 
Alatau, Tarbagatai, floodplains of the Aksu, Tentek, Irtysh, Ulba and Bukhtarma rivers. In the northern region of the West Kazakhstan oblast, there is one more important potential carrier of Lyme borreliosis - I. ricinus that is found here in single quantities. In addition, in the tugai forests of the Ili River valley in the Almaty region there is a relict and endemic spe-

cies of ticks, I. kazakstani, which is genetically closer to I. ricinus than to I. persulcatus [49]. There are other representatives of the genus Ixodes in Kazakhstan (figure 1) [50], but their role as carriers of Lyme borreliosis is unclear. Some of these species (e.g. I. pavlovskyi and I. crenulatus) are mainly associated with birds, not mammals.

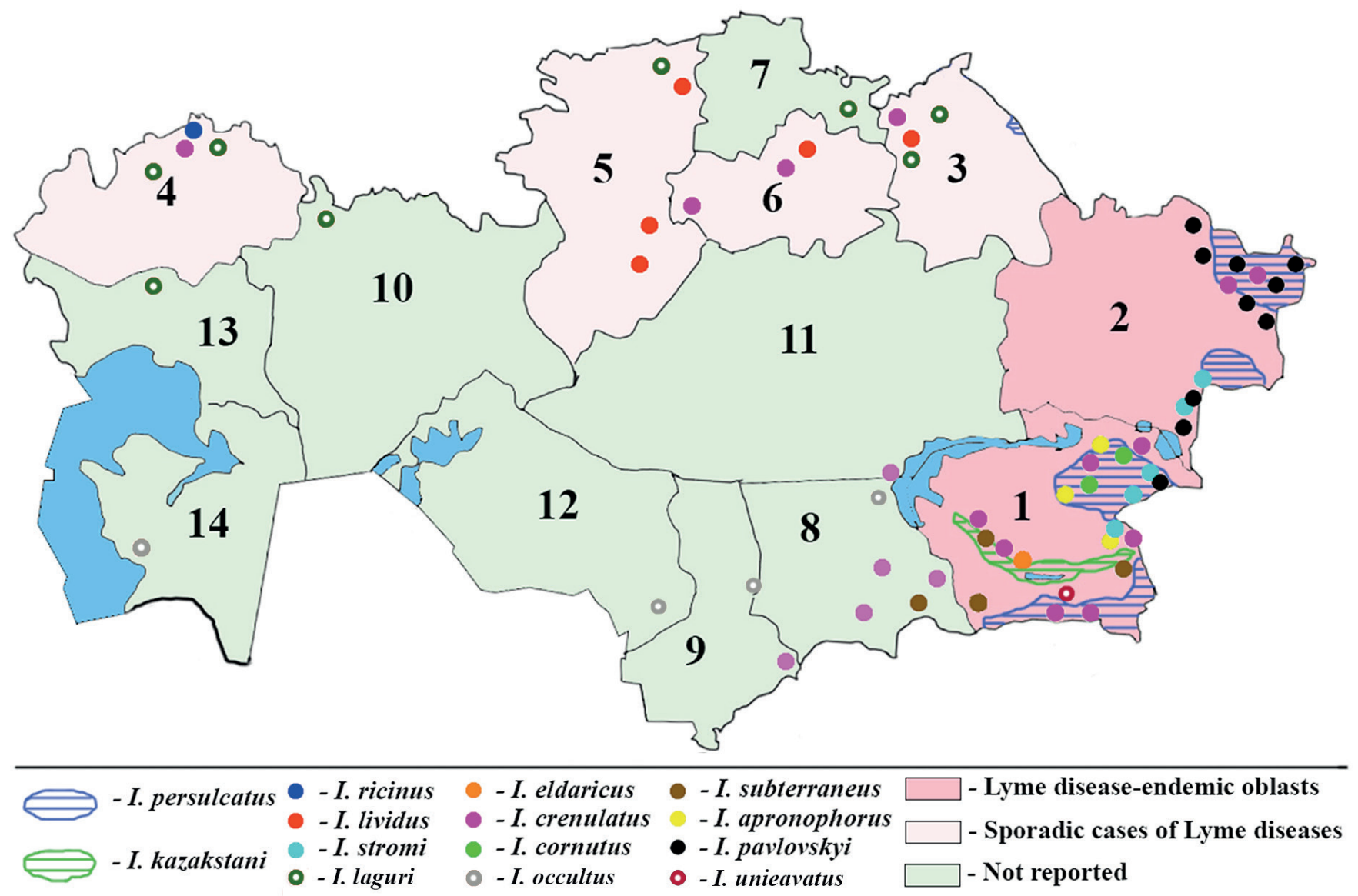

Area of Kazakhstan according to the risk of infection with Lyme disease:

1 - Almaty, 2- Eastern Kazakhstan, 3- Pavlodar, 4 - Western Kazakhstan, 5 - Kostanai, 6 - Akmola, 7 - Northern Kazakhstan, 8 - Zhambyl, 9 - Turkestan, 10 - Aktobe, 11 Karaganda, 12 - Kyzylorda, 13 - Atyrau, 14 - Mangystau.

Fig. 1. Distribution areas of ticks of genus Ixodes in Kazakhstan (according to [50] and data reported at scientific symposia)

The analysis of ticks collected in Lyme disease endemic areas showed the infection of ticks of the genus Ixodes with B. burgdorferi in the Almaty oblast to be $37.5 \%$, and in East Kazakhstan - 40.9\% [47].

The laboratory for especially dangerous infections at the Center of Sanitary Epidemiological Expertise of Eastern Kazakhstan oblast studies ticks and sera of febrile patients for the presence of Borreliella. So, in 2007-2009, 110 blood sera from patients with suspected tick-borne borreliosis were examined, and in 11 cases $(10 \%)$ the diagnosis of borreliosis was confirmed.

Currently, in areas of Kazakhstan endemic for tick-borne infections, there is a significant gap in the monitoring of persons bitten by ticks: ticks brought by victims are not examined for the presence of the causative agent of borreliosis, a comprehensive serological examination of patients in dynamics is not provided, making it hard to timely diagnose this disease. Since an incorrect etiological diagnosis is given and timely anti-epidemic and preventive measures are not carried out, there is an increase in the morbidity indicator of Lyme borreliosis in endemic regions.

The traditional two-stage testing procedure for borrelia infection in the USA and Europe is based on ELISA or indirect immunofluorescence, followed by testing of positive samples by immunoblotting [15]. Final serological testing is considered positive if both analyses have shown positive results. The countries 
of the European Union adhere to this practice, but in Kazakhstan this protocol has not been adopted, and the decision is made based on the results of one enzyme immunoassay, which may adversely affect the effectiveness of the diagnosis.

\section{CONCLUSION}

Ticks of the genus Ixodes, which are the main carriers of not only tick-borne encephalitis, but also causative agents of Lyme borreliosis (superspecies complex Borreliella burgdorferi sensu lato), are common in the mountain regions of East and South-East Kazakhstan. Some representatives of this genus are also found in the west and north of the country. At the same time, Lyme disease is not given proper attention: people bitten by ticks receive preventive treatment only from tick-borne encephalitis, and, with very few exceptions, it is the only pathogenic agent the ticks are analyzed for. Due to climate change, the distribution areas of ticks of the genus Ixodes are constantly expanding; these ticks are now found in areas where they have never been registered before. So, in areas non-endemic for the disease, the risk of incorrect diagnosis is high. The diagnosis is complicated by the unclear clinical symptoms in many patients, as well as the fact that Kazakhstan does not apply the protocol for confirming positive ELISA results by immunoblotting, adopted in the EU and the USA. Many cases can be attributed to other diseases similar to Lyme disease in symptoms. Conducting epidemiological studies, determining the diversity of borrelia species circulating throughout the country, as well as carrying out their genetic characterization are extremely important in the context of climate change and in the framework of the strategy to reduce the disease burden in Kazakhstan (in the absence of adequate treatment for Lyme borreliosis, the chance of developing severe chronic diseases of musculoskeletal and nervous systems is very high). The problem of Lyme borreliosis in Kazakhstan and the risks associated with this disease clearly need to be reassessed.

\section{Acknowledgements}

This work was supported by the Ministry of Education and Science of the Republic of Kazakhstan (grant No. AP05132856 «Identification and molecular-genetic characterisation of Borrelia sp. strains circulating within the territory of Kazakhstan in or- der to improve the system of epidemiological surveillance of tick-borne borreliosis»).

\section{REFERENCES}

1. Solovej N.V., Shherba V.V., Anis'ko L.A., Gorbich Ju.L., Danilov D.E., Karpov I.A. Lajm-borrelioz [Lyme Borreliosis]. Minsk, BSMU Publishing House. 2015. - 31 p.

2. Setubal J.C., Reis M., Matsunaga J., Haake D.A. Lipoprotein computational prediction in spirochaetal genomes. Microbiology, 2006, vol.152, pp. 113-121. 16385121. http://dx.doi.org/10.1099/ mic.0.28317-0.

3. Fraser C.M., Casjens S., Huang W.M., et al. Genomic sequence of a Lyme disease spirochaete, Borrelia burgdorferi. Nature, 1997, vol.390, pp 580586. 9403685 . http://dx.doi.org/10.1038/37551.

4. Adeolu M., Gupta R.S. A phylogenomic and molecular marker based proposal for the division of the genus Borrelia into two genera: the emended genus Borrelia containing only the members of the relapsing fever Borrelia, and the genus Borreliella gen. nov. containing the members of the Lyme disease Borrelia (Borrelia burgdorferi sensu lato complex). Antonie Van Leeuwenhoek, 2014, vol.105, no.6, pp. 1049-1072. PMID: 24744012. http://dx.doi. org/10.1007/s10482-014-0164-x.

5. Bergström S., Normark J. Microbiological features distinguishing Lyme disease and relapsing fever spirochetes. Wien. Klin. Woch., 2018, vol. 130, pp. 484-490. 30074091. http://dx.doi.org/10.1007/ s00508-018-1368-2.

6. Ružić-sabljić E., Cerar T. Borrelia Genotyping in Lyme Disease // Open Dermatology J. - 2016. - Vol. 10. - P. 6-14. http://dx.doi.org/10.2174/18743 72201610010006.

7. Stanek G., Wormser G.P., Gray J., Strle F. Lyme borreliosis. Lancet, 2012, vol. 379, pp. 461473. 21903253. http://dx.doi.org/10.1016/S01406736(11)60103-7.

8. Strle F., Stanek G. Clinical manifestations and diagnosis of Lyme borreliosis. Curr. Probl. Dermatology, 2009, vol. 37, pp. 51-110.21903253. http:// dx.doi.org/10.1016/S0140-6736(11)60103-7.

9. Van Dam A.P., Kuiper H., Vos K., Widjojokusumo A., et al. Different genospecies of Borrelia burgdorferi are associated with distinct clinical manifestations of Lyme borreliosis. Clin. Infect. Dis., 1993, vol.17, pp. 708-717. 7903558. http://dx.doi. 
org/10.1093/clinids/17.4.708.

10. Barbour A.G. Isolation and cultivation of Lyme disease spirochetes. Yale J. Biol. Medicine, 1984, vol. 57, pp. 521-525. 6393604.

11. Walker D.H., Barbour et al. Emerging bacterial zoonotic and vector-borne diseases: ecological and epidemiological factors. JAMA, 1996, vol. 275, pp. 463-499. 8627968. http://dx.doi.org/10.1001/ jama.1996.03530300047039.

12. Gorelova N.B., Korenberga E.I., et al. Small mammals as reservoir hosts for Borrelia in Russia. Zentr. Bakter., 1995, vol. 282, no. 3, pp. 315-322. 7549164. https://doi.org/10.1016/S09348840(11)80132-5.

13. Eugene D., Shapiro M.D. Lyme Disease. New England J. Medicine, 2014, vol. 370, no.18, pp. 17241731. https://doi.org/10.1056/NEJMcp1314325.

14. Balashov Yu.S. Blood-sucking ticks (Ixodoidea) are carriers of human and animal diseases. - Leningrad: Science, 1967. - 287 p.

15. HalperinJ.J.Lymedisease:anevidence-based approach. Wallingford, CAB International, 2018. 286 pp. https://doi.org/10.1079/9781786392077.0000.

16. Korenberg E.I. Comparative ecology and epidemiology of Lyme disease and tick-borne encephalitis in the former Soviet Union. Parasitology Today, 1994, vol. 10, no.4, pp. 157-160. 15275486. https://doi.org/10.1016/0169-4758(94)90269-0.

17. Biadun W., Stępień-Rukasz H., Rzymowska J., Niemczyk M. Occurrence of Borrelia burgdorferi sensu lato in Ixodes ricinus and Dermacentor reticulatusticks collected from roe deer and deer shot in the South-East of Poland. Bulletin- Veterinary Institute in Pulawy., 2007, vol. 51, no.2, pp. 213-217.

18. Karpov I.A., Solovej N.V., Anis'ko L.A., Shherba V.V., Danilov D.E. Lajm-borrelioz: voprosy diagnostiki i racional'noj jetiotropnoj terapii [Lyme borreliosis: issues of diagnosis and rational etiotropic therapy]. Klinicheskaja infektologija i parazitologija, 2015, vol. 3, no. 14, pp. 64-78.

19. Randolph S.E., Craine N.G. General framework for comparative quantitative studies on transmission of tick-borne diseases using Lyme borreliosis in Europe as an example. J. Med. Entomol., 1995, vol. 32, no.6, pp. 765-777. 8551498. https://doi. org/10.1093/jmedent/32.6.765.

20. Hanson M.S., Cassatt D.R., Guo B.P., et al. Active and passive immunity against Borrelia burgdorferi decorin binding protein $\mathrm{A}(\mathrm{DbpA})$ protects against infection. Infect. Immun., 1998, vol. 66, pp. 2143-2153. 9573101.
21. Fischer J.R., LeBlanc K.T., Leong J.M. Fibronectinbinding protein BBK32 of the Lyme disease spirochete promotes bacterial attachment to glycosaminoglycans. Infect Immun., 2006, vol.74, pp. 435-441. 16368999. https://doi.org/10.1128/ IAI.74.1.435-441.2006.

22. Goldstein S.F., Charon N.W., Kreiling J.A. Borrelia burgdorferi swims with a planarwaveformsimilar to that of eukaryotic flagella. PNAS USA, 1994, vol.91, pp. 3433-3437. 8159765. https://doi. org/10.1073/pnas.91.8.3433.

23. Casjens S., Palmer N., et al. A bacterial genome in flux: the twelve linear and nine circular extrachromosomal DNAs in an infectious isolate of the Lyme disease spirochete Borrelia burgdorferi. Mol. Microbiology, 2000, vol. 35, pp. 490-516. 10672174. https://doi.org/10.1046/j.1365-2958.2000.01698.x.

24. Steere A.C., Klitz W., Drouin E.E., et al. Antibiotic-refractory Lyme arthritis is associated with HLA-DR molecules that bind a Borrelia burgdorferi peptide. J. Exp. Medicine, 2006, vol. 203, pp. 961-971. 16585267. https://doi.org/10.1084/jem.20052471.

25. Baranton G., De Martino S.J. Borrelia burgdorferi sensu lato diversity and its influence on pathogenicity in humans. Curr. Probl. Derm., 2009. vol. 37, pp. 1-17. 19367094. https://doi. org/10.1159/000213066.

26. Kraiczy P., Stevenson B. Complement regulator-acquiring surface proteins of Borrelia burgdorferi: structure, function and regulation of gene expression. Ticks and Tick Borne Dis., 2013, vol. 4, pp. 26-34. 23219363. https://doi.org/10.1016/j.ttbdis.2012.10.039.

27. Alitalo A., Meri T., Rämö L., Jokiranta T.S., Heikkilä T., Seppälä I.J., Oksi J, Viljanen M., Meri S. Complement evasion by Borrelia burgdorferi: serum-resistant strains promote $\mathrm{C} 3 \mathrm{~b}$ inactivation. Infect. Immun., 2001, vol. 69, pp. 3685-3691. 11349031. https://doi.org/10.1128/IAI.69.6.3685-3691.2001.

28. Giambartolomei G.H., Dennis V.A., Philipp M.T. Borrelia burgdorferi stimulates the production of interleukin-10 in peripheral blood mononuclear cells from uninfected humans and rhesus monkeys. Infect. Immun., 1998, vol. 66, no.6, pp. 2691-2697. 9596735.

29. Schutzer S.E., Coyle P.K., Belman A.L., Golightly M.G., Drulle J. Sequestration of antibody to Borrelia burgdorferi in immune complexes in seronegative Lyme disease. Lancet, 1990, vol. 335, no. 8685, pp. 312-315. 1967770. https://doi. org/10.1016/0140-6736(90)90606-6.

30. Zhang J.R., Norris S.J. Genetic variation 
of the Borrelia burgdorferi gene vlsE involves cassette-specific, segmental geneconversion. Infect. Immun., 1998, vol. 66, pp. 3698-3704. 9673251.

31. Zhang J.R., Hardham J.M., Barbour A.G., Norris S.J. Antigenic variation in Lyme disease borreliae by promiscuous recombination of VMP-like sequence cassettes. Cell, 1997, vol. 89, no.2, pp. 275285. 9673251.

32. Cabello F.C., Godfrey H.P., Newman S.A. Hidden in plain sight: Borrelia burgdorferi and the extracellular matrix. Trends in Microbiology, 2007, vol. 15, pp. 350-354. 17600717. https://doi.org/10.1016/j. tim.2007.06.003.

33. Alaedini A., Latov N. Antibodies against OspA epitopes of Borrelia burgdorferi cross-react with neural tissue. J Neuroimmunol.. 2005, vol. 159, pp. 192-195. 15652419. https://doi.org/10.1016/j.jneuroim.2004.10.014.

34. Tibbles C.D., Edlow J.A. Does this patient have erythema migrans? JAMA, 2007, vol. 297, pp. 2617-2627. 17579230. https://doi.org/10.1001/ jama.297.23.2617.

35. Marques A. Lyme Disease: A Review. Curr. Allergy Asthma Rep., 2010, vol. 10, pp. 13-20. 20425509. https://doi.org/10.1007/s11882-009-0077-3.

36. Marques A. Chronic Lyme Disease: A Review. Infect. Dis. Clin. North Am., 2008, vol.22, no.2, pp. 341-360. 18452806. https://doi.org/10.1016/j. idc.2007.12.011.

37. Qureshi MZ, New D., Zulqarni N.J., Nachman S. Overdiagnosis and overtreatment of Lyme disease in children. Pediatr. Infect. Dis. J., 2002, vol.21, no.1, pp. 12-14. 11791091. https:/doi. org/10.1097/00006454-200201000-00003.

38. Swanson J.S., Neitzel D., Reed K.D., Belongia E.A. Coinfections acquired from Ixodes ticks. Clinical Microbiol. Revew., 2006, vol. 19, pp. 708-727. 17041141. https://doi.org/10.1128/CMR.00011-06.

39. Lee S.H., Vigliotti V.S., Vigliotti J.S., Jones W., Pappu S. Increased sensitivity and specificity of Borrelia burgdorferi 16S ribosomal DNA detection. Am. J, Clin, Pathol., 2010, vol. 133, no. 4, pp. 569576. 20231610. http://dx.doi.org/10.1309/AJCPI72YAXRHYHEE.

40. Neubert U., Schaller M., Januschke E., Stolz W., Schmieger H. Bacteriophages induced by ciprofloxacin in a Borrelia burgdorferi skin isolate. Zentr. Bakter., 1993, vol. 279, no. 3, pp. 307-315. 8219501.

41. Hanson M.S., Cassatt D.R., et al., Dorward D.W., Höök M. Active and passive immunity against
Borrelia burgdorferi decorin binding proteinA (DbpA) protects against infection. Infect Immun., 1998, vol. 66, pp. 2143-2145. 9573101.

42. Bergström S., Normark J. Microbiological features distinguishing Lyme disease and relapsing fever spirochetes. Wien Klin. Woch., 2018, vol. 130, pp. 484-490. 30074091. http://dx.doi.org/10.1007/ s00508-018-1368-2.

43. Lin T., Oliver J.H., et al. Genetic heterogeneity of Borrelia burgdorferi sensu lato in the southern United States based on restriction fragment length polymorphism and sequence analysis. J. Clin. Microbiol., 2001, vol. 39, pp. 2500-2507. 11427560. http:// dx.doi.org/10.1128/JCM.39.7.2500-2507.2001.

44. Liveris D., Gazumyan A., Schwartz I. Molecular typing of Borrelia burgdorferi sensu lato by PCR-restriction fragment length polymorphism analysis. J. Clin. Microbiol., 1995, vol. 33, pp. 589595. 7751362 .

45. Casjens Sh.R., Gilcrease E.B., et al. Plasmid diversity and phylogenetic consistency in the Lyme disease agent Borrelia burgdorferi. BMC Genomics, 2017, vol. 18, no.1. 165. 28201991. http://dx.doi. org/10.1186/s12864-017-3553-5.

46. Derdáková M., Lencáková D. Association of genetic variability within the Borrelia burgdorferi sensu lato with the ecology, epidemiology of Lyme borreliosis in Europe. Ann Agric Environ Med., 2005, vol.12, no.2, pp. 165-172. 16457468.

47. Egemberdieva R.A., Ermuhanova N.T., Dmitrovskij A.M. Jepidemiologicheskaja harakteristika nekotoryh kleshhevyh transmissivnyh infekcij v Kazahstane [Epidemiological characteristics of some tick-borne vector-borne infections in Kazakhstan]. Nacional'nye prioritety Rossii, 2013, vol. 2, no. 9, p. 92-94.

48. Kurmangalieva K.B., Atygaeva S.K., ZhAmburchinova A.N., Shirshikbaeva G.E. Sluchaj bolezni Lajma $\mathrm{v}$ nejendemichnom regione [A case of Lyme disease in a non-endemic region]. Zhurnal infektologii, 2014, vol. 4, no.1, p. 93-94.

49. Kovaleva S.Y., Fedorovab S.Zh., et al. Molecular features of Ixodes kazakstani: first results. Ticks and Tick-borne Diseases, 2018, vol. 9, no. 3, pp. 759-761. 29519771. http://dx.doi.org/10.1016/j.ttbdis.2018.02.019.

50. Filippova N.A. Iksodovye kleshhi podsemejstva Ixodonae. Fauna SSSR, tom IV- Paukoobraznye [Fauna USSR. Spiders. Ixodid ticks (Ixodinae)]. Leningrad, Nauka, 1977, vol.4, ser.4. - 316 p. 


\section{БОРЕЛИОЗ: КАЗАКСТАН ҮШІН ЖАСЫРЫН КАУІП}

Бисенбай А.О., Жигайлов А.В., Мальцева Э.Р., Егембердиева Р.А., Скиба Ю.А., Мамадалиев С.М.

Ұлттық биотехнология ортальгы, Алматы құаласындавы филиаль Жаһангер көшесі, 14, Алматы, 050054, Қазақстан.

andrzhig@yandex.ru

\section{ТУЙІН}

Кене боррелиозы (Лайм ауруы, Лайм-боррелиозы) - трансмиссиялық таралу механизмі бар табиғи ошақты зоонозды ауруы. Бұл ауру Borreliella burgdorferi sensu lato түрлер кешенінің боррелияларынан туындайды. Егер адамдарда емделмеген болса, бұл ауру жүйке жүйесінің, буындардың немесе терінің зақымдануына, сонымен қатар созылмалы атрофиялық ауруларға келтіруі мүмкін. Лайм-боррелиоздың клиникалық көрінісі полиморфизмінің тән ерекшелігі, бірнеше ағзалардың бір уақытта зақымдануына және ағзадағы коздырғыштың жиі жасырын түрде тұрақталуы ауруды диагностикалаудағы қателіктерге, кеш диагноз қоюға, медициналық көмек көрсетудегі ақауларға, қалдық салдардың жоғары жиілігіне, сонымен қатар науқастардың уақытша еңбекке жарамсыздығы мен мүгедектігі салдарынан ауыр әлеуметтік-экономикалық жағдайға әкелуі мүмкін. Ауруды негізгі таратушылары Ixodes кенелері Қазақстанның шығыс және оңтүстік-шығыс таулы аймақтарында кездеседі, бірақ климаттың өзгеруіне байланысты кенелердің таралу ареалының кеңейіп жатқанын атап өткен жөн және соның салдарынан кене боррелиозының табиғи ошақтары көбеюде. Осы ғылыми мақала эпидемиология, этиология, патогенез, Лайм-боррелиозының диагностикалау әдістері мен боррелиялардың талдауға арналған заманауи молекулалық-генетикалық әдістерге қатысты әдебиеттерді жаңартуға, сонымен қатар Қазақстан үшін осы аурумен байланысты қауіп-қатерді бағалауға бағытталған.

Негізгі сөздер: Лайм ауруы, Borreliella burgdorferi sensu lato, Ixodes, эритема, генотиптеу, генетикалық түрлер. 


\section{БОРРЕЛИОЗ: СКРЫТАЯ УГРОЗА ДЛЯ КАЗАХСТАНА}

Бисенбай А.О., Жигайлов А.В., Мальцева Э.Р., Егембердиева Р.А., Скиба Ю.А., Мамадалиев С.М.

Национальный иентр биотехнологии, филиал в г.Алмать, ул. Жахангер, 14, Алматы, 050054, Казахстан.

andrzhig@yandex.ru

\section{АБСТРАКТ}

Клещевой боррелиоз (болезнь Лайма, Лайм-боррелиоз) - природно-очаговое, зоонозное заболевание с трансмиссивным механизмом передачи, вызывающееся боррелиями видового комплекса Borreliella burgdorferi sensu lato. При отсутствии лечения у людей заболевание может вызывать поражения в нервной системе, суставах или в кожном покрове, акродерматит, а также хронические атрофические заболевания. Характерные для Лайм-боррелиоза полиморфность клинической картины, одновременное поражение нескольких органов и частое латентное персистирование возбудителя в организме могут приводить к ошибкам в диагностике заболевания, поздней постановке диагноза, дефектам в оказании медицинской помощи, высокой частоте остаточных последствий и, как следствие, к серьезным социальноэкономическим потерям, связанным с временной нетрудоспособностью и инвалидностью переболевших пациентов. Основным переносчиком болезни являются клещи рода Ixodes. Представители этого рода клещей встречаются в восточном и юго-восточном регионах Казахстана, и в этих регионах страны периодически происходят случаи заражения людей Лайм-боррелиозом. Настоящая статья направлена на обновление литературных данных в отношении эпидемиологии, этиологии, патогенеза, методов диагностики Лайм-боррелиоза и современных молекулярно-генетических методов анализа боррелий, а также на оценку рисков, связанных с данным заболеванием, для Казахстана.

Ключевые слова: Лайм-боррелиоз, боррелии, Borreliella burgdorferi sensu lato, Ixodes, эритема, генотипирование, геновид. 